Vol 1 No 22020 Desember 2020

Jurnal AlphaEuclidEdu

Received: 21/10/2020; Revised: 27/11/2020; Accepted: 03/12/2020

\title{
KEMAMPUAN KOMUNIKASI MATEMATIS SISWA DIKAJI DARI SELF CONFIDENCE
}

\author{
${ }^{\mathbf{1}}$ Putri, Tjut Aflianti Eka, ${ }^{\mathbf{2} J a m i a h, ~ Y u l i s, ~}{ }^{\mathbf{3}}$ Sayu, Silvia \\ 1,2,3Pendidikan Matematika FKIP Universitas Tanjungpura Pontianak
}

Email: tjutaflianti@gmail.com

\begin{abstract}
The purpose of this research is to describe the mathematical communication skills of students assessed from self confidence in the material system of two-variable linear equations in SMP Muhammadiyah 1 Pontianak. The method in this research is descriptive research method with survey research. The sample of the research were the students of IX A SMP Muhammadiyah 1 Pontianak. Research subjects were 28 students. From the results of the self confidence questionnaire, obtained data of 6 students having a low level of self confidence and 22 students having a high level of self confidence. In addition to administering questionnaires, students were also given mathematical communication skills test and interview questions. From the results of tests and interviews obtained written mathematical communication skills of subjects with low levels of self confidence can fulfill one of the four indicators of mathematical communication skills. While the verbal mathematical communication skills of subjects with low self confidence levels can fulfill two of the four indicators of mathematical communication skills. In addition, subjects with high levels of self confidence can fulfill all indicators of mathematical communication skills both in writing and verbal.

Keywords: Mathematical Communication, Self Confidence
\end{abstract}

\section{Pendahuluan}

Pemerintah tak henti-hentinya berupaya dalm memajukan kualitas pendidikan di Indonesia. Mulai dari memberikan berbagai macam pelatihan kepada guru-guru serta memperbaharui kurikulum. Namun hingga saat ini hasil yang didapatkan dari upaya tersebut belum optimal. Fakta tersebut dapat dilihat dari rata-rata nilai ujian nasional SMP tahun 2018 yaitu 52,96 yang mengalami penurunan dari ujian nasional SMP tahun 2017 yang memperoleh nilai rata-rata 55,51. Fakta lain juga menunjukkan bahwa ratarata nilai UN tingkat Sekolah Menengah Pertama (SMP) tahun 2018 khususnya pelajaran matematika yang juga mengalami penurunan (Putri, 2018: 1). Menurut pengamat pendidikan, Indra Charismiadji, salah satu penyebab rendahnya nilai matematika adalah metode pendidikan yang belum sesuai. Menurut (Syahmadani, 2018: 1) hal ini disebabkan model pembelajaran pada saat ini diajarkan di sekolah masih berada di tingkat menghafal dan memahami.

Ansari (2016: 4) berpendapat perlu adanya reformasi model pembelajaran matematika di kelas untuk mengantisipasi kemajuan teknologi dan perkembangan ilmu pengetahuan. Tugas dan peran guru tidak hanya penyampai informasi (transfer of knowledge), melainkan selaku pengerak belajar (simulation of learning) yang bertujuan supaya siswa bisa membangun sendiri pengetahuan dengan berbagai macam kegiatan pemecahan masalah, berkomunikasi (doing math) dan penalaran demi sarana siswa untuk melatihan berpikir kritis dan kreatif. Peraturan menteri pendidikan dan kebudayaan No 21 Tahun 2016 menegaskan bahwa salah satu yang harus ada pada 
siswa adalah kemampuan mengomunikasikan suatu gagasan matematika dengan tepat. Oleh karena itu, kemampuan komunikasi matematis harus ditumbuhkembangkan dalam dunia pendidikan dari sejak dini.

Baroody (Ansari, 2016: 5) berpendapat setidajnya ada dua macam alasan, pentingnya mengembangkan komunikasi dalam pelajaran matematika. Pertama, mathematics as language, dapat diartikan matematika bukan hanya alat bantu saat berpikir (a tool to aid thinking), alat dalam mendapatkan pola, mengambil kesimpulan atau memecahkan masalah, melainkan matematika dapat menjadi salah satu alat untuk mengomunikasikan ide-ide secara cermat dan jelas. Kedua, mathematics learning as social activity; artinya pembelajaran matematika selaku kegiatan sosial, matematika juga berupa sarana penghubung antar siswa serta komunikasi terhadap guru dan siswa. Hal tersebut menunjukkan pentingnya untuk mempercepat pemahaman matematika siswa. Greenes dan Schulman (Nuraeni dan Luritawaty, 2016: 102) menyatakan bahwa komunikasi matematis merupakan kekuatan utama bagi siswa untuk menyusun konsep dan strategi matematika; seumpama modal kesuksesan siswa terhadap pendekatan dan penyelesaian saat eksplorasi dan investigasi matematika; komunikasi menjadi tempat bagi siswa untuk memperoleh informasi atau berbagi pikiran, menilai dan menajamkan ide untuk meyakinkan seseorang.

Dalam kegiatan belajar mengajar, komunikasi yang terjadi haruslah komunikasi multi arah diantara guru dan siswa bisa diartikan siswa akan memberi respon setelah guru selesai menjelaskan suatu hal, misalnya berupa pertanyaan-pertanyaan jika ketika guru menyampaikan masih ada yang kurang dimengerti maka siswa akan dengan spontan akan menanyakan bagian yang masih belum dipahami. Guru juga sebaiknya memahami bentuk komunikasi yang efektif agar pesan yang ingin disampaikan kepada siswa lebih mudah dipahami. Komunikasi yang tercipta pun bukan hanya sekedar komunikasi lisan, melainkan dapat pula komunikasi secara tertulis. Menurut Los Angeles Country Office of Education (dalam Mahmudi, 2009: 3) menjelaskan bahwa komunikasi matematik terdiri dari dua cakupan yaitu komunikasi tertulis dan lisan. Komunikasi tertulis dapat berupa, gambar, table, penggunaan kata-kata, dan sebagainya yang dapat menggambarkan proses berpikir siswa. Komunikasi tertulis juga dapat berbentuk uraian pemecahan masalah atau pembuktian matematika yang menggambarkan kemampuan siswa dalam mengkontruksi berbagai konsep penyelesaikan masalah. Sedangkan komunikasi lisan dapat berbentuk ungkapan dan penjelasan verbal suatu gagasan matematika. Komunikasi lisan bisa terjadi melalui interaksi antar siswa contohnya dalam pembelajaran yang disetting agar siswa dapat berdiskusi antar kelompok.

Pentingnya membangun komunikasi yang baik saat proses pembelajaran juga dijelaskan oleh Herdian (2010: 1) yang mana telah ia berpendapat saat proses belajar mengajar matematika di kelas, komunikasi gagasan matematika dapat terjadi antar siswa dengan siswa, guru dengan siswa, dan buku dengan siswa. Baiknya komunikasi yang tercipta dapat memberikan pengaruh positif kepada siswa sehingga siswa memiliki tanggung jawab untuk menciptakan suasana belajar yang baik. Siswa yang merasa 
Vol 1 No 22020 Desember 2020

Jurnal AlphaEuclidEdu

bahwa mereka terlibat secara aktif dalam proses pembelajaran dapat membantu meningkatnya rasa percaya diri siswa saat mengikuti proses belajar. Rasa percaya diri yang baik dapat memacu siswa untuk lebih mudah menyampaikan pendapatnya tentang materi yang dipelajari.

Percaya diri atau sering disebut Self Confidence sangat diperlukan siswa untuk mengomunikasikan berbagai macam keluhan yang didapat saat belajar. Rakhmat (2012: 107) mengungkapkan bahwa masalah-masalah yang dialami siswa dalam komunikasi akan menyebabkan siswa yang rendah percaya diri sering menghindari momen komunikasi, sehingga saat diskusi berlangsung siswa akan lebih banyak diam. Pendapat itu sependapat dengan penelitian yang dilaksanakan oleh Jumalia (2018: 59) yang menunjukkan bahwa kepercayaan diri mempengaruhi kemampuan komunikasi matematika sebanyak $74,1 \%$ pada hasil belajar. Pentingnya self confidence dalam dunia pendidikan tercantum didalam Permendikbud No. 21 Tahun 2016 tentang standar isi, yang memuat bahwa percaya diri merupakan satu diantara sikap sosial yang harus dimiliki siswa.

Untuk menguatkan dugaan-dugaan tersebut, peneliti melakukan prariset di kelas VIII C SMP Muhammadiyah 1 Pontianak pada tanggal 12 Februari 2019, berupa pemberian soal tes Sistim Persamaan Linear Dua Variabel (SPLDV) dan angket self confidence. Dari hasil prariset tersebut, diperoleh rata-rata nilai tes yang diberikan kepada 29 orang siswa pada materi SPLDV yaitu 35,17. Dapat dikatakan bahwa ratarata nilai saat pemberian tes cukup jauh dibawah nilai ketuntasan belajar minimum (KBM) matematika yaitu 70. Berdasarkan hasil jawaban beberapa siswa diperoleh fakta bahwa siswa belum bisa menggunakan simbol-simbol matematika dengan benar, siswa belum mampu untuk mengubah situasi matematika menjadi ide matematika berupa SPLDV, siswa belum mampu menganalisis strategi apa yang pada digunakan untuk menyelesaikan suatu persoalan. Berdasarkan permasalahan yang telah diuraikan, terdapat indikasi ternyata kemampuan komunikasi matematis siswa dikategorikan rendah saat mengerjakan soal terkait berhubungan dengan materi SPLDV.

Selain pemberian soal tes kemampuan komunikasi matematis, peneliti juga memberikan angket untuk mengetahui self confidence yang dimiliki siswa. Berdasarkan hasil angket yang diberikan kepada 29 siswa kelas VIII C, diperoleh 15 siswa yang kurang percaya akan kemampuan dirinya sendiri. Selain itu, terdapat 14 siswa yang merasa frustasi jika mendapatkan nilai rendah. Rasa frustasi ini menunjukkan bahwa mereka memberikan reaksi yang kurang baik terhadap kegagalan yang dialami. Terdapat pula 16 siswa yang tidak berani mengerjakan soal di papan tulis dan 15 siswa yang belum berani mengajukan pertanyaan. Fakta ini diperkuat dari hasil wawancara peneliti terhadap beberapa siswa yang mengaku belum berani bertanya karena takut mendapatkan penolakan, baik dari guru maupun teman sekelas. Berdasarkan hasil angket dan wawancara tersebut, peneliti mengasumsikan bahwa masih terdapat siswa yang memiliki tingkat self confidence rendah.

Hasil tes dan angket yang telah diberikan sejalan dengan pernyataan Rakhmat (2012:103) yang menyatakan bahwa orang yang minder akan menemui kerumitan 
Vol 1 No 22020 Desember 2020

Jurnal AlphaEuclidEdu

dalam mengomunikasikan idenya pada orang yang diseganu, tidak sanggup berbicara di depan umum, atau ragu-ragu menyampaikan pandangannya. Naim (2017: 91) juga menyatakan bahwa seorang pembicara yang kurang percaya diri, akan menciptakan timbulnya rasa takut karena ia akan menjadi pusat perhatian banyak orang.

Menurut NCTM (2000: 60) faktor yang penyebab rendahnya kemampuan komunikasi matematis dikarenakan matematika lebih dominan disampaikan dalam bentuk simbol, sehingga komunikasi lisan maupun tertulis tentang ide-ide matematika tidak selalu menjadi bagian penting dari pendidikan matematika. Selain itu pada penelitian yang dilakukan oleh Darkasyi (2014: 22) menampakkan bahwa guru cenderung lebih aktif dibandingkan siswa, dimana guru lebih sering menerapkan metode ceramah saat penyampaian materi. Pembelajaran dengan metode ceramah dapat membuat siswa tidak terbiasa untuk mengomunikasikan gagasan yang mereka miliki serta hanya fokus dengan penyampaian yang diberikan oleh guru. Anggapan tersebut sepaham dengan hasil penelitian yang telah dilaksanakan oleh Shimada (2006: 63) yang menunjukkan pada saat pembelajaran, seorang guru memiliki peran lebih banyak dan penyampaian yang didapat hanya berjalan satu arah, yaitu dari guru terhadap siswa, dengan demikian dapat menyebabkan siswa menjadi tidak aktif. Sedangkan Kurikulum 2013 lebih menekankan pembelajaran aktif, dimana guru hanya menuntun siswa untuk mencari tahu sehinga proses belajar mengajar lebih berpusat kepada siswa.

Berdasarkan Silabus Mata Pelajaran Matematika tingkat SMP Kurikulum 2013, materi SPLDV merupakan satu diantara materi yang wajib dipahami dan dikuasai oleh siswa dalam pembelajaran matematika. Selain itu, dari hasil wawancara pada guru matematika kelas VIII ditanggal 11 Februari 2019, diketahui bahwa nilai siswa pada materi SPLDV mengalami penurunan. Fakta tersebut juga didukung dengan pemberian soal SPLDV pada saat prariset, dimana rata-rata siswa hanya mampu mengerjakan 2 soal dengan benar dari 4 butir soal yang diberikan. Salah satu penyebab materi SPLDV dianggap sulit karena materi ini menuntut siswa untuk mengomunikasikan ide-ide matematikanya agar dapat menyelesaikan permasalahan.

Berdasarkan uraian sebelumnya, maka peneliti melakukan penelitian yang berjudul "Kemampuan Komunikasi Matematis Siswa Dikaji Dari Self Confidence Pada Materi Sistem Persamaan Linear Dua Variabel Di SMP Muhammadiyah 1 Pontianak".

\section{Metode Penelitian}

Metode penelitian adalah upaya ilmiah untuk mengumpulkan data dengan maksud dan tujuan tertentu (Sugiyono, 2015: 24). Metode penelitian yang diterapkan pada penelitian ini adalah metode penelitian deskriptif, karena tujuannya memberikan pandangan tentang kemampuan komunikasi matematis siswa yang dikaji dari self confidence. Subjek penelitian dibatasi sebanyak enam siswa dengan rincian tiga siswa yang mempunyai tingkat self confidence rendah dan tiga siswa dengan tingkat self confidence tinggi.

Metode penelitian deskriptif adalah metode penelitian yang dilakukan untuk menjelaskan dengan akurat, terperinci dan nyata mengenai sifat dan fakta pada populasi tertentu. Dalam penelitian deskriptif hanya menggambarkan sesuatu apa adanya, tidak 
Vol 1 No 22020 Desember 2020

Jurnal AlphaEuclidEdu

untuk mencari atau menerangkan keterkaitan antar variabel (Sanjaya, 2013: 59). Penelitian ini akan melihat dan mendeskripsikan fakta di lapangan mengenai kemampuan komunikasi matematis dikaji dari self confidence dalam materi SPLDV apa adanya.

\subsection{Tahap Persiapan}

Langkah-langkah yang dilaksanakan saat tahap persiapan yaitu: (1) Melakukan prariset; (2) Membuat instrumen penelitian yang berupa kisi-kisi angket tingkat self confidence, angket tingkat self confidence, kisi-kisi tes kemampuan komunikasi matematis, soal tes kemampuan komunikasi matematis, kunci jawaban tes kemampuan komunikasi matematis, rubrik penskoran tes kemampuan komunikasi matematis, pedoman wawancara dan kisi-kisi wawancara; (3) Melaksanakan validasi pada instrumen penelitian; (4) Melakukan revisi instrumen tes berdasarkan pada hasil validasi; (5) Melaksanakan uji coba instrumen penelitian di SMP Islam Al-Azhar 17 Pontianak; (6) Menganalisis hasil uji coba instrumen penelitian; (7) Mengatur jadwal pelaksanaan penelitian dengan menanyakan pada guru matematika.

\subsection{Tahap Pelaksanaan}

Langkah-langkah persiapan antara lain: (1) Memberikan angket tingkat self confidence kepada siswa; (2) Menganalisis angket tingkat self confidence siswa; (3) Mengelompokkan siswa berdasarkan tingkat self confidence (rendah dan tinggi) yang diperoleh dari hasil angket tingkat self confidence; (4) Menetapkan subjek penelitian yaitu tiga orang dengan tingkat self confidence rendah, dan tiga orang dengan tingkat self confidence tinggi; (5) Memberikan soal tes kemampuan komunikasi matematis kepada subjek penelitian; (6) Mewawancarai subjek penelitian untuk melengkapi informasi yang diperoleh dari hasil tes; (7) Menganalisis hasil tes kemampuan komunikasi matematis dan wawancara berdasarkan tingkat self confidence siswa.

\subsection{Tahap Pengolahan Data}

Langkah-langkah pada saat mengolah data meliput: (1) Mendeskripsikan hasil analisis tes kemampuan komunikasi matematis dan wawancara berdasarkan pada tingkat self confidence rendah dan self confidence tinggi; (2) Membuat laporan hasil penelitian.

\section{Hasil dan Pembahasan}

\subsection{Hasil Penelitian}

Angket self confidence diberikan kepada 28 siswa kelas IX A SMP Muhammadiyah 1 Pontianak yang berisi 32 item pernyataan (16 item pernyataan favourable dan 16 item pernyataan unfavourable yang mencakup unsur-unsur melihat tingkat self confidence siswa. Data dari hasil angket yang telah dijawab siswa, selanjutnya diolah dengan bantuan Microsoft Excel. Interpretasi skor skala self confidence tidak bisa dilakukan secara langsung sehingga peneliti mengubah respon subjek dengan skor angka. Untuk mendapatkan hasil dari skor angka, peneliti mengubah respon subjek tiap item pernyataan menjadi sebuah skor berdasarkan pernyataan favourable dan unfavourable. Hasil angket self confidence siswa kelas IX A SMP Muhammadiyah 1 Pontianak dapat dilihat pada Gambar 1 dibawah ini: 
Vol 1 No 22020 Desember 2020

Jurnal AlphaEuclidEdu

Gambar 1: Representasi Tingkat Self Confidence Siswa Kelas IX A di SMP

Muhammadiyah 1 Pontianak

Berdasarkan hasil angket self confidence, diperoleh data bahwa sebanyak 6 orang mempunyai tingkat self confidence rendah dan 22 siswa mempunyai self confidence tinggi. Dari 28 siswa yang telah dikelompokkan pada masing-masing tingkat self confidence, peneliti mengambil tiga siswa secara acak yang memiliki tingkat self confidence rendah yaitu RR, AK, dan RP, serta tiga siswa yang memiliki tingkat self confidence tinggi yaitu SA, MA, dan AA.

Setelah memilih subjek berdasarkan tingkat self confidence, selanjutnya peneliti memberikan soal tes kemampuan komunikasi matematis kepada ke enam subjek tersebut yang terdiri dari lima soal essay. Pemberian tes ini dimaksudkan untuk mengungkap bagaimana kemampuan komunikasi matematis siswa yang akan dianalisis dan dijabarkan dalam bentuk narasi berdasarkan indikator kemampuan komunikasi matematis. Dari hasil penelitian yang telah diteliti, peneliti membuat rangkuman deskripsi kemampuan komunikasi matematis siswa dikaji dari tingkat self confidence pada tabel 1 berikut:

Tabel 1

Kemampuan Komunikasi Matematis Dikaji Dari Tingkat Self Confidence

\begin{tabular}{|c|c|c|}
\hline $\begin{array}{c}\text { Subjek } \\
\text { Penelitian }\end{array}$ & $\begin{array}{l}\text { Tingkat Self } \\
\text { Confidence }\end{array}$ & Deskripsi Kemampuan Komunikasi Matematis \\
\hline $\mathrm{RR}$ & Rendah & $\begin{array}{l}\text { Dari } 5 \text { soal yang diberikan, subjek RR hanya dapat } \\
\text { mengerjakan } 2 \text { soal. Secara tertulis dan lisan, Subjek RR } \\
\text { kurang baik dalam menyatakan situasi ke dalam ide } \\
\text { matematis, menganalisis dan mengevaluasi ide matematis } \\
\text { dalam penyelesaian permasalahan yang diberikan, } \\
\text { menggunakan simbol matematika serta mengungkapkan } \\
\text { kembali hasil penyelesaian soal. }\end{array}$ \\
\hline AK & Rendah & $\begin{array}{l}\text { Dari } 5 \text { soal yang diberikan, subjek AK dapat mengerjakan } \\
4 \text { soal. Secara tertulis dan lisan, subjek AK baik dalam } \\
\text { menggunakan simbol matematika. Secara lisan, subjek } \\
\text { AK juga baik dalam menyatakan situasi ke dalam ide } \\
\text { matematis. }\end{array}$ \\
\hline RP & Rendah & $\begin{array}{l}\text { Subjek RP mengerjakan } 4 \text { dari } 5 \text { soal yang diberikan. } \\
\text { Secara tertulis, Subjek RP kurang baik dalam menyatakan } \\
\text { situasi ke dalam ide matematis, menganalisis dan } \\
\text { mengevaluasi ide matematis, serta mengungkapkan } \\
\text { kembali hasil penyelesaian soal. Namun ia tergolong baik } \\
\text { dalam menggunakan simbol matematika. Sedangkan } \\
\text { secara lisan, subjek RP tergolong baik dalam menyatakan } \\
\text { situasi ke dalam ide matematis, menggunakan simbol } \\
\text { matematika, dan mengungkapkan kembali hasil }\end{array}$ \\
\hline
\end{tabular}




\begin{tabular}{ccc}
\hline & penyelesaian soal. \\
& Subjek AA dapat mengerjakan 5 soal yang diberikan. \\
& Selain itu, subjek AA berada dalam kategori baik dalam \\
menyatakan situasi ke dalam ide matematis, menganalisis & Tan mengevaluasi ide matematis dalam menyelesaikan \\
AA & soal, menggunakan simbol matematika, serta \\
mengungkapkan kembali hasil penyelesaian soal.
\end{tabular}

\subsection{Pembahasan}

\subsubsection{Analisis Hasil Tes Tertulis}

Berdasarkan hasil penelitian, diperoleh data mengenai kemampuan komunikasi matematis dikaji dari self confidence dalam materi SPLDV di SMP Muhammadiyah 1 Pontianak, dengan jumlah 28 siswa diketahui bahwa siswa kelas IX A SMP Muhammadiyah 1 Pontianak memiliki tingkat self confidence yang berbeda-beda yaitu 6 siswa mempunyai tingkat self confidence rendah dan 22 siswa mempunyai tingkat self confidence tinggi. Demikian juga hasil analisis data pada soal tes dan wawancara diketahui bahwa kemampuan komunikasi matematis siswa berbeda-beda dan tergantung dari tingkat self confidence yang dimilikinya. Hal ini sejalan dengan pernyataan Sidik dkk (2017: 226) bahwa kemampuan komunikasi matematis yang dimiliki siswa bervariasi tergantung pada tingkat self confidence yang dimiliki.

Berdasarkan hasil analisis data kemampuan komunikasi matematis subjek RR, AK, dan RP yang memiliki tingkat self confidence rendah, diperoleh fakta bahwa 
kemampuan komunikasi matematis tertulis ketiga subjek hanya memenuhi satu dari empat indikator kemampuan komunikasi matematis, yaitu menggunakan simbol-simbol matematika dalam menyelesaikan permasalahan. Sedangkan secara lisan, ketiga subjek dapat memenuhi dua indikator kemampuan komunikasi matematis, yaitu indikator menggunakan simbol-simbol matematika dalam menyelesaikan permasalahan, serta indikator mengungkapkan kembali hasil penyelesaian soal. Siswa dengan tingkat self confidence rendah belum dapat dikatakan memiliki kemampuan komunikasi matematis karena tidak memenuhi seluruh indikator. Hasil analisis data ini sejalan dengan penelitian yang dilakukan Subekti \& Kusuma (2016: 445) bahwa siswa dengan self confidence rendah belum dapat memenuhi semua indikator kemampuan komunikasi matematis.

Berdasarkan hasil tes dan wawancara peneliti terhadap subjek RR, AK dan RP pada indikator mengungkapkan kembali hasil penyelesaian soal terdapat kesamaan antara ketiga subjek, yaitu secara tertulis tidak semua soal yang mereka kerjakan terdapat kesimpulan dari hasil penyelesaian soal. Namun secara lisan, ketiganya dapat mengungkapkan kembali hasil penyelesaian soal yang telah mereka kerjakan. Ketiga subjek tersebut juga tidak dapat menyelesaikan seluruh soal yang diberikan. Subjek AK dan RP dapat menyelesaikan 4 soal, sedangkan subjek RR hanya dapat menyelesaikan 2 soal. Fakta tersebut menunjukkan bahwa siswa dengan tingkat self confidence rendah kurang mampu dalam menganalisis soal.

Berdasarkan analisis hasil wawancara, siswa cenderung mudah menyerah dan memilih jalan pintas dengan meminta bantuan teman dalam proses pengerjaan soal tersebut. Hal ini dilakukan oleh subjek AK dalam proses pengerjaan soal nomor 2 dan 4. Selain itu ketiga subjek juga terlalu lama dalam memahami maksud soal sehingga mereka kehabisan waku untuk menyelesaikan seluruh soal. Dengan sikap tersebut, kemampuan komunikasi matematis siswa yang memiliki tingkat self confidence rendah juga tergolong rendah. Hasil analisis data yang didapat sesuai dengan penelitian yang diteliti oleh Noviyana dkk (2019: 708) bahwa siswa yang memiliki tingkat self confidence rendah akan sulit mendapatkan prestasi yang baik karena siswa tersebut selalu berpikiran negatif dan tidak yakin terhadap kemampuannya sendiri. Selain itu, hasil analisis data ini sesuai dengan pendapat yang diungkapkan Mark Twin (dalam Ubaedy, 2007: 73) yang menyatakan bahwa kepercayaan diri adalah sesuatu yang dibutuhkan untuk meraih prestasi.

Siswa yang memiliki tingkat self confidence rendah juga mudah menyerah dan tidak memiliki keinginan untuk di-perjuangkan. Mereka juga lebih sering memposisikan diri sebagai yang terakhir dan sering kali melakukan hal yang dapat merusak kepercayaan orang lain. Sebagai contoh, siswa yang memiliki tingkat self confidence rendah cenderung mengikuti apa yang sudah diputuskan oleh teman sekelompok saat diskusi kelompok terjadi. Mereka juga kurang termotivasi untuk maju atau memperbaiki kekurangan diri yang mereka rasakan, seperti merasa tidak percaya diri saat ulangan karena tidak belajar atau tidak berani bertanya ke guru saat mereka kurang mengerti tentang materi yang sedang diajarkan. Hasil analisis data ini sesuai dengan pendapat 
Vol 1 No 22020 Desember 2020

Jurnal AlphaEuclidEdu

Ubaedy (2007: 72) bahwa orang dengan tingkat self confidence rendah biasanya tidak sanggup menciptakan bukti diri positif.

Sedangkan berdasarkan hasil analisis data kemampuan komunikasi matematis subjek AA, SA, dan MA yang memiliki tingkat self confidence tinggi, diperoleh fakta bahwa kemampuan komunikasi matematis tertulis dan lisan siswa yang memiliki self confidence tinggi bisa memenuhi seluruh indikator kemampuan komunikasi matematis, yaitu indikator mengungkapkan situasi dan gambar ke dalam ide matematis, indikator menganalisis dan mengevaluasi ide matematika dalam menyelesaikan per-masalahan, indikator menggunakan simbol-simbol matematika dalam menyelesaikan permasalahan, serta indikator mengungkapkan kembali hasil penyelesaian soal dengan baik. Siswa dengan tingkat self confidence tinggi ini sudah dapat dikatakan memiliki kemampuan komunikasi matematis yang baik karena dapat memenuhi seluruh indikator kemampuan komunikasi matematis.

Untuk siswa yang mempunyai tingkat self confidence tinggi cenderung mampu mengerjakan seluruh soal dengan baik. Baik lisan maupun tertulis, kemampuan komunikasi matematis siswa yang memiliki tingkat self confidence tinggi tergolong baik. Fakta berdasarkan hasil analisis ini sesuai dengan pendapat Rizqi dkk (2016: 91) bahwa dengan self confidence yang baik, siswa dapat mengkomunikasikan ide-ide mereka untuk mengklarifikasi pemecahan masalah yang mereka peroleh.

Jika dilihat dari hasil wawancara yang telah dilakukan, siswa dengan tingkat self confidence tinggi memiliki pandangan yang baik terhadap kemampuan yang dimiliki. Mereka juga cenderung berani menanggung konsekuensi dari apa yang mereka lakukan. Hal ini dapat terlihat saat mereka menemukan jawaban yang berbeda saat proses diskusi kelompok. Mereka berani mengalah jika memang jawaban yang mereka temukan ternyata salah. Hasil analisis data ini sesuai dengan penelitian yang dilakukan oleh Noviyana dkk (2019: 708) dimana hasil penelitian menghasilkan kemampuan komunikasi matematis siswa akan bagus jika siswa tersebut memiliki rasa percaya diri yang baik, karena pandangan positif mengenai dirinya dan kemampuannya mengakibatkan siswa tidak merasa takut salah ataupun cemas ketika menyelesaikan masalah tentang komunikasi matematis. Siswa yang memiliki self confidence yang baik juga akan berani menyampaikan pendapatnya serta akan terdorong untuk meningkatkan prestasinya.

\section{Kesimpulan}

Dari hasil analisis data yang dijabarkan dan pembahasan, umumnya bisa disimpulkan bahwa siswa dengan self confidence tinggi bisa memenuhi seluruh indikator kemampuan komunikasi matematis, namun siswa dengan tingkat self confidence rendah belum dapat memenuhi semua indikator dari kemampuan komunikasi matematis.

Secara khusus bisa disimpulkan yakni:

1. Kemampuan komunikasi matematis tertulis dikaji dari tingkat self confidence rendah dapat memenuhi indikator menggunakan simbol-simbol matematika dalam menyelesaikan permasalahan 
Vol 1 No 22020 Desember 2020

Jurnal AlphaEuclidEdu

2. Kemampuan komunikasi matematis tertulis dikaji dari self confidence tinggi bisa memenuhi seluruh indikator kemampuan komunikasi matematis.

3. Kemampuan komunikasi matematis lisan dikaji dari tingkat self confidence rendah dapat indikator menggunakan simbol-simbol matematika, dan indikator mengungkapkan kembali hasil penyelesaian soal dengan baik.

4. Kemampuan komunikasi matematis lisan dikaji dari self confidence tinggi bisa memenuhi seluruh indikator kemampuan komunikasi matematis.

\section{Referensi}

\section{Referensi berupa buku}

Ansari, Bansu I. 2016. Komunikasi Matematik Strategi Berfikir dan Manajemen Belajar: Konsep dan Aplikasi. Aceh: Pena.

Naim, Ngainun. 2017. Dasar-dasar Komunikasi Pendidikan. Yogyakarta: Ar-ruzz Media.

Rakhmat, Jalaluddin. 2012. Psikologi Komunikasi. Bandung: Remaja Rosdakarya.

Sanjaya, Wina. 2013. Penelitian Pendidikan (Jenis, Metode, dan Prosedur). Jakarta: Kencana Prenada Media Grup.

Sugiyono. 2015. Metode Penelitian Manajemen. Bandung: Alfabeta.

Ubaedy, AN. 2007. Berfikir Positif: Agar Anda Tetap Pede Menghadapi Hidup. Jakarta: Bee Media Indonesia.

\section{Referensi berupa jurnal online tanpa DOI}

Darkasyi, Muhammad, dkk. 2014. Peningkatan Kemampuan Komunikasi Matematis dan Motivasi Siswa dengan Pembelajaran Pendekatan Quantum Learning pada Siswa SMP Negeri 5 Lhokseumawe. Jurnal Didaktik Matematika Vol. 1 No. 1.

Herdian. 2010. Kemampuan Komunikasi Matematika. (Online). (http://herdy07_wordpress.com, 25 Mei 2018)

Mahmudi, Ali. 2009. Komunikasi dalam Pembelajaran Matematika. Jurnal MIPMIPA UNHALU Vol. 8 No.1.

Noviyana, I. N, dkk. 2019. Analisis Kemampuan Komunikasi Matematis Siswa Ditinjau Dari Self Confidence. Prosiding Seminar Nasional Matematika.

Nuraeni, R \& Luritawaty, I.P. 2016. Mengembangkan Kemampuan Komunikasi Matematik Siswa Melalui Strategi Think Talk Write. Jurnal Pendidikan Matematika STKIP Garut.

Putri, Zunita Amalia. 2018. Kemendikbud: Nilai Rata-rata UN SMP 2018 Alami Penurunan. Detik News.

Rizqi, A.A; Suyitno, H; \& Sudarmin. 2016. Analysis of Mathematical Communication Abilitu Viewed from Students Confidence through Blended Learning. International Conference on Mathematics, Science, and Education 2016.

Sidik, Anwar; Ramlah; \& Utami, M. R. 2017. Hubungan Antara Self Confidence Dengan Kemampuan Komunikasi Matematis Siswa SMP. Prosiding Seminar Nasional Matematika dan Pendidikan Matematika (SESIOMADIKA). 
Vol 1 No 22020 Desember 2020

Jurnal AlphaEuclidEdu

Subekti, F. E. \& Kusuma, A. B. 2016. Deskripsi Kemampuan Komunikasi Matematis Ditinjau Dari Rasa Percaya Diri Mahasiswa. Jurnal Euclid Vol.3 No.1.

Syahmadani, K. Anam. 2018. Logika Siswa Rendah, Nilai Unas SMP Turun. Jawa Pos.

\section{Referensi berupa Chapter Book}

NCTM. 2000. Principles and Standards for School Mathematics. Reston, VA: NCTM.

Shimada, S. 2006. Senior Secondary Education Project 2006. The Open Ended Approach. A New Tesis for Teaching Mathematics. Reston: Prentice Hall Inc.

\section{Referensi berupa Undang-Undang atau Peraturan Pemerintah}

Kemendikbud. 2016. Standar Isi Pendidikan Dasar dan Menengah. Jakarta:

Kementerian Pendidikan dan Kebudayaan Republik Indonesia.

\section{Referensi berupa Skripsi/Tesis/Disertasi}

Jumalia. 2018. Pengaruh Kepercayaan Diri dan Kemampuan Komunikasi Matematika Terhadap Hasil Belajar Matematika Siswa Kelas VIII SMP Negeri 5 Majene. Makassar: Skripsi Universitas Negeri Makassar. 